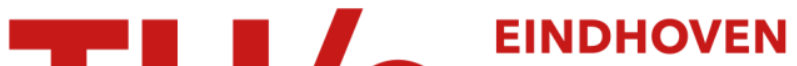 UNIVERSITY OF TECHNOLOGY
}

\section{Iron sulphide containing hydrodesulfurization catalysts : Mössbauer study of the sulfidibility of alpha-iron(III) oxide}

\section{Citation for published version (APA):}

Ramselaar, W. L. T. M., Beer, de, V. H. J., \& Kraan, van der, A. M. (1988). Iron sulphide containing hydrodesulfurization catalysts : Mössbauer study of the sulfidibility of alpha-iron(III) oxide. Applied Catalysis, 42(1), 153-167. https://doi.org/10.1016/S0166-9834(00)80083-4

DOI:

10.1016/S0166-9834(00)80083-4

Document status and date:

Published: 01/01/1988

\section{Document Version:}

Publisher's PDF, also known as Version of Record (includes final page, issue and volume numbers)

\section{Please check the document version of this publication:}

- A submitted manuscript is the version of the article upon submission and before peer-review. There can be important differences between the submitted version and the official published version of record. People interested in the research are advised to contact the author for the final version of the publication, or visit the $\mathrm{DOI}$ to the publisher's website.

- The final author version and the galley proof are versions of the publication after peer review.

- The final published version features the final layout of the paper including the volume, issue and page numbers.

Link to publication

\section{General rights}

Copyright and moral rights for the publications made accessible in the public portal are retained by the authors and/or other copyright owners and it is a condition of accessing publications that users recognise and abide by the legal requirements associated with these rights.

- Users may download and print one copy of any publication from the public portal for the purpose of private study or research.

- You may not further distribute the material or use it for any profit-making activity or commercial gain

- You may freely distribute the URL identifying the publication in the public portal.

If the publication is distributed under the terms of Article 25fa of the Dutch Copyright Act, indicated by the "Taverne" license above, please follow below link for the End User Agreement:

www.tue.nl/taverne

Take down policy

If you believe that this document breaches copyright please contact us at:

openaccess@tue.nl

providing details and we will investigate your claim. 


\title{
Iron Sulphide Containing Hydrodesulphurization Catalysts
}

\section{Mössbauer Study of the Sulphidibility of $\alpha$-Iron(III) Oxide}

\author{
W.L.T.M. RAMSELAAR \\ Interfacultair Reactor Instituut, Delft University of Technology, Mekelueg 15, $2629 \mathrm{JB}$ Delft \\ (The Netherlands)
}

V.H.J. DE BEER

Laboratory for Inorganic Chemistry and Catalysis, Eindhoven University of Technology, P.O. Box 513, $5600 \mathrm{MB}$ Eindhoven (The Netherlands)

and

\author{
A.M. VAN DER KRAAN* \\ Interfacultair Reactor Instituut, Delft University of Technology, Mekelweg 15, $2629 \mathrm{JB}$ Delft \\ (The Netherlands)
}

(Received 25 January 1988, accepted 23 March 1988)

\begin{abstract}
As a first step in the study of the sulphidation of carbon-supported iron oxide catalyst systems the sulphiding of a well-characterized, unsupported model compound, viz. $\alpha$-Fe $\mathrm{O}_{2} \mathrm{O}_{3}$ (mean particle diameter ca. $50 \mathrm{~nm}$ ) was investigated using in-situ Mössbauer spectroscopy and the temperatureprogrammed sulphiding technique. Sulphidation was carried out in a flow of $10 \%$ hydrogen sulphide in hydrogen. At room temperature and atmospheric pressure no bulk sulphidation of the $\alpha$ $\mathrm{Fe}_{2} \mathrm{O}_{3}$ particles was observed. However, as the sulphidation temperature increased a direct transformation of bulk $\alpha-\mathrm{Fe}_{2} \mathrm{O}_{3}$ into iron sulphides took place. The iron-to-sulphur ratio of the iron sulphides formed during the sulphidation process was initially 2 and decreased to 1 with increasing sulphidation time and/or temperature.
\end{abstract}

\section{INTRODUCTION}

Hydrotreating catalysts are important within the oil-refining industry. Treatment with 5-15 MPa hydrogen at $600-700 \mathrm{~K}$ in the presence of aluminasupported $\mathrm{Co}-\mathrm{Mo}$ and $\mathrm{Ni}$-Mo sulphide catalysts removes carbon-bonded impurities such as sulphur, nitrogen, oxygen, nickel and vanadium via so-called hydrodesulphurization (HDS), hydrodenitrogenation (HDN), hydrodeoxy- 
genation (HDO) and hydrodemetallization (HDM) reactions. Recently, it was shown that sulphided $\mathrm{Fe}_{2} \mathrm{O}_{3}$ well dispersed on a carbon support, has promising properties as a hydrotreating catalyst $[1,2]$.

In the preparation of these catalysts, sulphidation of the oxidic catalyst precursor is a crucial step because it results in the formation of the actual active catalyst. Therefore, it is important to know how this sulphidation proceeds and whether the final result (type of sulphide and its dispersion) depends upon the sulphiding conditions applied. In general, the sulphiding process of oxidic catalyst precursors has hardly been studied so far. Recently, a temperatureprogrammed sulphiding (TPS) technique was developed and sucessfully applied [3-8]. In the case of iron- [9] or cobalt- [10,11] containing HDS catalysts, in-situ Mössbauer spectroscopy was shown to be an excellent technique for the study of the transition of oxide catalyst precursors to their sulphided state.

As a first step in our study of the sulphidation of carbon-supported iron oxide catalyst systems the present paper describes the sulphiding of a well-characterized, unsupported, model compound, viz. $\alpha-\mathrm{Fe}_{2} \mathrm{O}_{3}$. The techniques applied were in-situ Mössbauer spectroscopy and TPS.

During sulphiding of $\alpha-\mathrm{Fe}_{2} \mathrm{O}_{3}$ the iron sulphides $\mathrm{Fe}_{1-x} \mathrm{~S}$ (pyrrhotites) and $\mathrm{FeS}_{2}$ (pyrite) were formed. However, in the former a wide range of solid solutions existed between $x=0$ and $x=0.18$. The non-stoichiometry of the iron sulphide system was attributed to the presence of iron vacancies [12]. It was reported that due to variations in the ordering of the iron vacancies different stable phases could exist at room temperature. This is reviewed briefly in the following section.

\section{THE IRON MONOSULPHIDE SYSTEM}

Besides the minerals troilite $(\mathrm{FeS})$ and pyrrhotite $\left(\mathrm{Fe}_{7} \mathrm{~S}_{8}\right)$, the iron monosulphide system also includes artificially prepared $\mathrm{Fe}_{1-x} \mathrm{~S}$ compounds with $-0.02 \leqq x \leqq 0.18$.

Above about $400 \mathrm{~K}$ the stoichiometric mineral troilite and the near stoichiometric $\mathrm{Fe}_{1-x} \mathrm{~S}$ compounds with $-0.02 \leqq x \leqq 0.04$ have the regular NiAs structure, which is called the $1 \mathrm{C}$-type structure. Below $400 \mathrm{~K}$ these compounds show a hexagonal superstructure [13] derived from the NiAs structure in such a way that the length of the crystallographic $c$-axis is twice as large as that of the $1 \mathrm{C}$ type structure and is therefore called the $2 \mathrm{C}$-type structure. In the temperature range 200 to $400 \mathrm{~K}$ the $1 \mathrm{C}$-type structure, as well as the $2 \mathrm{C}$-type structure, can exist for these compounds. In the basic crystallographic structure the relatively large sulphur ions are hexagonally close-packed, while the smaller iron ions preferentially occupy the octahedral sites and are arranged in layers.

It is obvious that, due to the close packing of the sulphur ions, the nonstoichiometry of the iron monosulphide system has to be attributed to the pres- 
ence of iron vacancies [12]. These vacancies are randomly distributed in the range $0<x<0.09$. In this range the compounds show the $1 \mathrm{C}$-type structure above $200 \mathrm{~K}$ and the $2 \mathrm{C}$-type structure below $200 \mathrm{~K}$. When $x>0.09$, ordering of the iron vacancies leads to stable phases at room temperature which differ with respect to the stacking sequence of iron-deficient layers. Since a clearly defined and generally accepted convention does not exist, the name troilite will be used for all phases exhibiting vacancy disorder, while the term pyrrhotite will be used for all phases exhibiting vacancy order. So, both the 1C- and $2 \mathrm{C}$-type structures will be called troilite like the stoichiometric mineral $\mathrm{FeS}$. In the composition range where the iron vacancies are ordered, the $3 \mathrm{C}$ - and $4 \mathrm{C}$-type structure are observed at room temperature [14-17]. The nominal composition of these stable phases corresponds to $\mathrm{Fe}_{7} \mathrm{~S}_{8}$ which means $x=0.125$. The difference between 3C- and 4C-type structures lies in the stacking sequence of the iron-deficient layers.

The troilite-pyrrhotite system has been extensively studied by various techniques in order to determine its magnetic as well as electrical properties. As the effective magnetic hyperfine field at an iron nucleus is dependent on the number of surrounding iron atoms, their distances and configurations, Mössbauer spectroscopy was used by Igaki et al. [18] to investigate the iron vacancy distribution in single crystals of $\mathrm{Fe}_{1-x} \mathrm{~S}$ in the range $0.083 \leqq x \leqq 0.125$. These authors took the iron vacancies within the third-nearest neighbouring positions into account and the iron sites were designated by the number of vacancies in each of the nearest, second-nearest and third-nearest neighbouring positions, labelled $\mathrm{C}, \mathrm{A}$ and $\mathrm{B}$, respectively.

In the region of vacancy order, Thiel [19] investigated by means of Mössbauer spectroscopy, the pyrrhotite $\mathrm{Fe}_{7} \mathrm{O}_{8}$ in the $3 \mathrm{C}$-type structure as well as the $4 \mathrm{C}$-type structure. The temperature dependence of hyperfine interactions in the near-stoichiometric $\mathrm{Fe}_{1-x} \mathrm{~S}$ (troilite) in the $1 \mathrm{C}$-structure region as well as the $2 \mathrm{C}$-structure region was studied by Thiel and Van den Berg [20].

\section{EXPERIMENTAL}

Experiments were carried out on a mixture of $75 \mathrm{mg} \alpha-\mathrm{Fe}_{2} \mathrm{O}_{3}$ (BASF, mean particle size $=50 \mathrm{~nm}$ ) and $225 \mathrm{mg} \mathrm{SiO}$, (Aerosil $300 \mathrm{~V}$ ) which was pressed into self supporting wafers with a diameter of $22 \mathrm{~mm}$, using a pressure of 8-10 MPa.

Sulphidation of the $\alpha-\mathrm{Fe}_{2} \mathrm{O}_{3}$ was carried out in an in-situ Mössbauer reactor similar to the one described previously [21,22], the only difference being that the reactor used in the present investigation was made of stainless steel. Sulphiding took place in a $10 \%$ hydrogen sulphide, in hydrogen gas mixture at a flow-rate of $1 \mathrm{~cm}^{3} / \mathrm{s}$. Before sulphidation was started, the reactor was flushed with argon, $1 \mathrm{~cm}^{3} / \mathrm{s}$ for $30 \mathrm{~min}$ at room temperature. During the sulphiding procedure the following temperature program was apllied: $30 \mathrm{~min}$ at room temperature, linear increase to the desired maximum reaction temperature in $1 \mathrm{~h}$, 
holding at this temperature for a certain time and cooling (in the hydrogen sulphide-hydrogen flow) to room temperature. The samples used for Mösshauer analysis were denoted either by $\mathrm{Fe}_{2} \mathrm{O}_{3}(y \mathrm{~K})$ where $y$ is the maximum sulphiding temperature which, in all cases, was reached within $1 \mathrm{~h}$ or by $\mathrm{Fe}_{2} \mathrm{O}_{3}$ $(y \mathrm{~K}, z \mathrm{~h})$ with $z$ being the time during which the sample was additionally kept at the maximum sulphiding temperature.

While the reactor was still filled with the sulphiding gas mixture the Mössbauer experiments were performed at room temperature with a constant acceleration spectrometer using a ${ }^{57} \mathrm{Co}$ in rhodium source. The spectra shown were not corrected for the varying distance between source and absorber and hence the curved background in the spectra was of instrumental origin. Isomer shifts are given relative to sodiumnitroprusside (SNP) at room temperature. Magnetic fields were calibrated with the $51.5 \mathrm{~T}$ field of $\alpha-\mathrm{Fe}_{2} \mathrm{O}_{3}$ at $293 \mathrm{~K}$. The Mössbauer spectra were deconvoluted by computer with calculated subspectra consisting of Lorentzian-shaped lines, whereas the curved background was accounted for by a parabola.

A detailed description of the TPS equipment and procedure was given elsewhere $[3,5]$. At the start of the TPS experiment the reactor containing $38 \mathrm{mg}$ $\alpha-\mathrm{Fe}_{2} \mathrm{O}_{3}$ was flushed with argon. Then, the sulphiding gas mixture $(3.3 \%$ hydrogen sulphide, $29.1 \%$ hydrogen and $68.6 \%$ argon) was led through the reactor at about $293 \mathrm{~K}$. The composition of the gas leaving the reactor was continuously monitored. Hydrogen sulphide was detected using an UV detector set at $215 \mathrm{~nm}$, hydrogen was detected by a thermal conductivity detector after water and hydrogen sulphide had been trapped in molecular sieves. When the hydrogen sulphide uptake at room temperature was completed the temperature of the TPS reactor was increased to about $1270 \mathrm{~K}$ at a rate of $10 \mathrm{~K} /$ $\min$.

\section{RESULTS}

\section{Mössbauer spectrometry}

First, the effect of hydrogen sulphide-hydrogen treatment at room temperature was studied. The Mössbauer spectrum obtained after $6 \mathrm{~h}$ exposure of the $\alpha-\mathrm{Fe}_{2} \mathrm{O}_{3}$ particles to the hydrogen sulphide-hydrogen gas mixture was not changed by this exposure.

Fig. 1a shows room temperature Mössbauer spectra of the samples $\mathrm{Fe}_{2} \mathrm{O}_{3}(423$ $\mathrm{K}), \mathrm{Fe}_{2} \mathrm{O}_{3}(473 \mathrm{~K}), \mathrm{Fe}_{2} \mathrm{O}_{3}(523 \mathrm{~K}), \mathrm{Fe}_{2} \mathrm{O}_{3}(573 \mathrm{~K})$ and $\mathrm{Fe}_{2} \mathrm{O}_{3}(673 \mathrm{~K})$, respectively. It is obvious that the spectral contribution of the $\alpha-\mathrm{Fe}_{2} \mathrm{O}_{3}$ sextuplet decreased as the final sulphiding temperature increased and that this coincided with the appearance of several newly-formed six-line patterns with much smaller magnetic hyperfine splittings. Besides these patterns of magnetically 


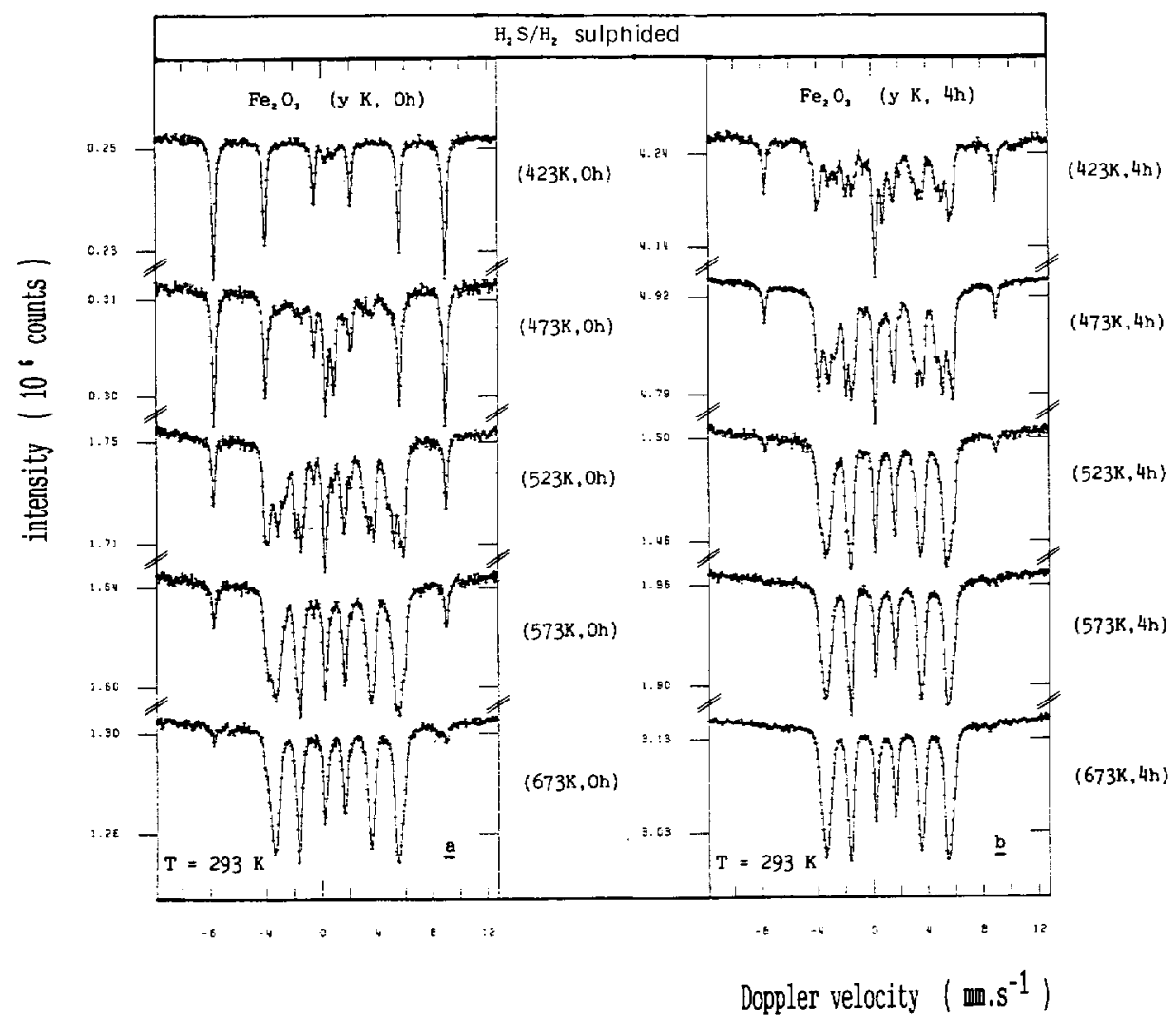

Fig. 1. (a) In-situ Mössbauer spectra at $293 \mathrm{~K}$ of sulphided $\mathrm{Fe}_{2} \mathrm{O}_{3}(y \mathrm{~K})$ samples. (b) In-situ Mössbauer spectra at $293 \mathrm{~K}$ of sulphided $\mathrm{Fe}_{2} \mathrm{O}_{3}(y \mathrm{~K}, 4 \mathrm{~h})$. See Experimental for details of the sulphidation procedure and sample notation.

split components an electric quadrupole doublet was also observed in the centre of the spectra of the samples sulphided up to either $473 \mathrm{~K}$ or $523 \mathrm{~K}$.

In order to follow how the sulphidation of $\alpha-\mathrm{Fe}_{2} \mathrm{O}_{3}$ proceeded we also continued the treatment in hydrogen sulphide-hydrogen for $4 \mathrm{~h}$ at the selected final sulphiding temperatures. In Fig. 1b the corresponding room temperature Mössbauer spectra are shown. Comparison of the spectra presented in Figs. 1a and $1 \mathrm{~b}$ clearly shows that the $\alpha-\mathrm{Fe}_{2} \mathrm{O}_{3}$ contribution decreased as with the sulphiding temperature and sulphiding time increased. It is also evident that the doublet present in the centre of the spectra $\mathrm{Fe}_{2} \mathrm{O}_{3}(423 \mathrm{~K}), \mathrm{Fe}_{2} \mathrm{O}_{3}(473 \mathrm{~K})$ and $\mathrm{Fe}_{2} \mathrm{O}_{3}(523 \mathrm{~K})$ in Fig. 1a and the $\mathrm{Fe}_{2} \mathrm{O}_{3}(423 \mathrm{~K}, 4 \mathrm{~h}), \mathrm{Fe}_{2} \mathrm{O}_{3}(473 \mathrm{~K}, 4 \mathrm{~h})$ spectra in Fig. $1 \mathrm{~b}$ could be ascribed to a compound which was formed at the beginning of the sulphiding process at temperatures below $473 \mathrm{~K}$. When the sulphiding process at $473 \mathrm{~K}$ was continued for $4 \mathrm{~h}$ the central doublet almost disappeared. It follows from the isomer shift (IS) and quadrupole splitting (QS) values 


\section{TABLE 1}

Mössbauer parameters at $293 \mathrm{~K}$ of sulphided $\mathrm{Fe}_{2} \mathrm{O}_{3}(y \mathrm{~K})$ samples

\begin{tabular}{|c|c|c|c|}
\hline \multirow[t]{2}{*}{$y$} & \multicolumn{3}{|c|}{ Sulphided $\mathbf{F e}_{2} \mathrm{O}_{3}(y \mathrm{~K})$ samples } \\
\hline & $523 \mathrm{~K}$ & $573 \mathrm{~K}$ & $673 \mathrm{~K}$ \\
\hline \multicolumn{4}{|l|}{$\alpha-\mathrm{Fe}_{2} \mathrm{O}_{3}$} \\
\hline IS $(\mathrm{mm} / \mathrm{s})$ & 0.69 & 0.71 & 0.73 \\
\hline $\mathrm{QS}(\mathrm{mm} / \mathrm{s})$ & 0.07 & 0.09 & 0.10 \\
\hline$H_{\text {eff }}(\mathrm{kOe})$ & 515 & 515 & 517 \\
\hline $\mathrm{A}(\%)$ & 16 & 12 & 7 \\
\hline \multicolumn{4}{|l|}{$\mathrm{FeS}_{2}$} \\
\hline IS $(\mathrm{mm} / \mathrm{s})$ & 0.57 & & \\
\hline $\mathrm{QS}(\mathrm{mm} / \mathrm{s})$ & 0.61 & & \\
\hline $\mathrm{A}(\%)$ & 3 & & \\
\hline \multicolumn{4}{|l|}{$\mathrm{Fe}_{1-x} \mathrm{~S}$} \\
\hline IS $(\mathrm{mm} / \mathrm{s})$ & 0.97 & 0.98 & 1.00 \\
\hline $\mathrm{QS}(\mathrm{mm} / \mathrm{s})$ & -0.06 & -0.07 & -0.07 \\
\hline$I_{\mathrm{eff}}(\mathrm{kOe})$ & 301 & 301 & 296 \\
\hline $\mathrm{A}(\%)$ & 32 & 22 & 25 \\
\hline IS $(\mathrm{mm} / \mathrm{s})$ & & 0.99 & 1.01 \\
\hline $\mathrm{QS}(\mathrm{mm} / \mathrm{s})$ & & -0.05 & -0.06 \\
\hline$H_{\mathrm{eff}}(\mathrm{kOe})$ & & 277 & 276 \\
\hline $\mathrm{A}(\%)$ & & 30 & 44 \\
\hline IS $(\mathrm{mm} / \mathrm{s})$ & 0.96 & 0.98 & 0.99 \\
\hline $\mathrm{QS}(\mathrm{mm} / \mathrm{s})$ & -0.04 & -0.07 & -0.09 \\
\hline$H_{\mathrm{eff}}(\mathrm{kOe})$ & 259 & 257 & 261 \\
\hline $\mathrm{A}(\%)$ & 33 & 36 & 24 \\
\hline IS $(\mathrm{mm} / \mathrm{s})$ & 0.93 & & \\
\hline $\mathrm{QS}(\mathrm{mm} / \mathrm{s})$ & -0.10 & & \\
\hline$H_{\text {eff }}(\mathrm{kOe})$ & 229 & & \\
\hline $\mathrm{A}(\%)$ & 16 & & \\
\hline
\end{tabular}

Experimental uncertainties: IS $= \pm 0.02 ; \mathrm{QS}= \pm 0.05 ; H_{\mathrm{eff}}= \pm 2 ; \mathrm{A}= \pm 5$.

obtained after computer deconvolution of the spectra, that the observed doublet could be ascribed to pyrite $\left(\mathrm{FeS}_{2}\right)$ (see Tables 1 and 2).

From Figs. 1a and $1 \mathrm{~b}$ it follows that both an increase in sulphiding temperature or sulphiding time influenced the resonant absorption pattern of the newly formed compounds with magnetic hyperfine splittings, indicating a change in composition and/or crystallographic structures. The observed range of magnetic hyperfine fields corresponded to that of non-stoichiometric $\mathrm{Fe}_{1-x} \mathrm{~S}$ compounds [18-20]. For the samples $\mathrm{Fe}_{2} \mathrm{O}_{3}(473 \mathrm{~K}), \mathrm{Fe}_{2} \mathrm{O}_{3}(523 \mathrm{~K})$ and 


\section{TABLE 2}

Mössbauer parameters at $293 \mathrm{~K}$ of sulphided $\mathrm{Fe}_{2} \mathrm{O}_{3}(y \mathrm{~K}, 4 \mathrm{~h})$ samples

\begin{tabular}{|c|c|c|c|c|c|}
\hline \multirow[t]{2}{*}{$y$} & \multicolumn{5}{|c|}{ Sulphided $\mathrm{Fe}_{2} \mathrm{O}_{3}(y \mathrm{~K}, 4 \mathrm{~h})$ samples } \\
\hline & $423 \mathrm{~K}$ & $473 \mathrm{~K}$ & $523 \mathrm{~K}$ & $573 \mathrm{~K}$ & $673 \mathrm{~K}$ \\
\hline \multicolumn{6}{|l|}{$\alpha-\mathrm{Fe}_{2} \mathrm{O}_{3}$} \\
\hline IS $(\mathrm{mm} / \mathrm{s})$ & 0.69 & 0.70 & 0.72 & & \\
\hline $\mathrm{QS}(\mathrm{mm} / \mathrm{s})$ & 0.07 & 0.07 & 0.1 & & \\
\hline$H_{\mathrm{eff}}(\mathrm{kOe})$ & 516 & 516 & 517 & & \\
\hline $\mathrm{A}(\%)$ & 13 & 9 & 5 & & \\
\hline \multicolumn{6}{|l|}{$\mathrm{FeS}_{2}$} \\
\hline IS $(\mathrm{mm} / \mathrm{s})$ & 0.57 & 0.57 & & & \\
\hline $\mathrm{QS}(\mathrm{mm} / \mathrm{s})$ & 0.61 & 0.61 & & & \\
\hline $\mathrm{A}(\%)$ & 21 & 2 & & & \\
\hline \multicolumn{6}{|l|}{$\mathrm{Fe}_{1-x} \mathrm{~S}$} \\
\hline IS $(\mathrm{mm} / \mathrm{s})$ & 0.95 & 0.97 & 0.98 & 0.99 & 1.00 \\
\hline $\mathrm{QS}(\mathrm{mm} / \mathrm{s})$ & -0.05 & -0.06 & -0.07 & -0.06 & -0.06 \\
\hline$H_{\text {eff }}(\mathrm{kOe})$ & 300 & 301 & 300 & 296 & 295 \\
\hline $\mathrm{A}(\%)$ & 29 & 33 & 28 & 36 & 32 \\
\hline IS $(\mathrm{mm} / \mathrm{s})$ & & & 0.99 & 1.00 & 1.00 \\
\hline $\mathrm{QS}(\mathrm{mm} / \mathrm{s})$ & & & -0.04 & -0.05 & -0.06 \\
\hline$H_{\mathrm{eff}}(\mathrm{kOe})$ & & & 275 & 275 & 277 \\
\hline A $(\%)$ & & & 35 & 44 & 43 \\
\hline IS $(\mathrm{mm} / \mathrm{s})$ & 0.96 & 0.95 & 0.98 & 0.99 & .1 .00 \\
\hline $\mathrm{QS}(\mathrm{mm} / \mathrm{s})$ & -0.03 & -0.04 & -0.08 & -0.10 & -0.10 \\
\hline$H_{\text {eff }}(\mathrm{kOe})$ & 255 & 258 & 258 & 259 & 261 \\
\hline $\mathrm{A}(\%)$ & 21 & 37 & 32 & 20 & 25 \\
\hline $\mathrm{IS}(\mathrm{mm} / \mathrm{s})$ & 0.95 & 0.93 & & & \\
\hline $\mathrm{QS}(\mathrm{mm} / \mathrm{s})$ & -0.10 & -0.09 & & & \\
\hline$H_{\text {eff }}(\mathrm{kOe})$ & 225 & 229 & & & \\
\hline $\mathrm{A}(\%)$ & 16 & 19 & & & \\
\hline
\end{tabular}

Experimental uncertainties: $\mathrm{IS}= \pm 0.02 ; \mathrm{QS}= \pm 0.05 ; H_{\mathrm{eff}}= \pm 2 ; \mathrm{A}= \pm 5$.

$\mathrm{Fe}_{2} \mathrm{O}_{3}(423 \mathrm{~K}, 4 \mathrm{~h}), \mathrm{Fe}_{2} \mathrm{O}_{3}(473 \mathrm{~K}, 4 \mathrm{~h})$ the spectrum of the sulphidic compound consisted of at least three distinct magnetic hyperfine sextuplets. As a result of increasing the sulphiding time and/or temperature the differences in the observed magnetic hyperfine fields became smaller. Besides the spectral contribution of the doublet in the centre and the sextuplet of the original $\alpha-\mathrm{Fe}_{2} \mathrm{O}_{3}$ particles, we used three different magnetic hyperfine sextuplets in the deconvolution procedure. The numerical Mössbauer parameters, (IS, QS and the 


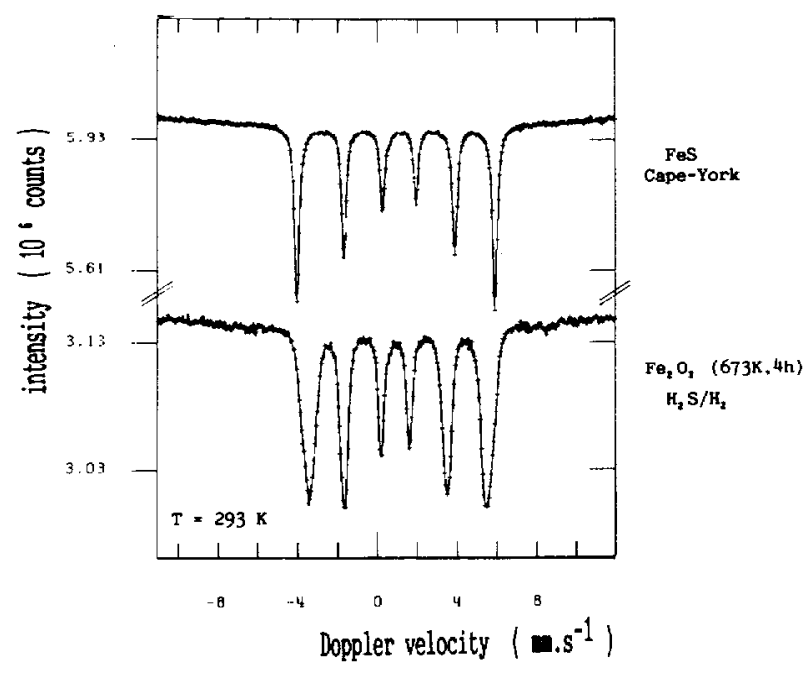

Fig. 2. Mössbauer spectrum at $293 \mathrm{~K}$ of stoichiometric troilite ( $\mathrm{FeS}$ ) from the meteorite CapeYork, and in-situ Mössbauer spectrum at $293 \mathrm{~K}$ of the sulphided $\mathrm{Fe}_{2} \mathrm{O}_{3}(673 \mathrm{~K}, 4 \mathrm{~h})$ sample. See Experimental for details of the sulphidation procedure and sample notation.

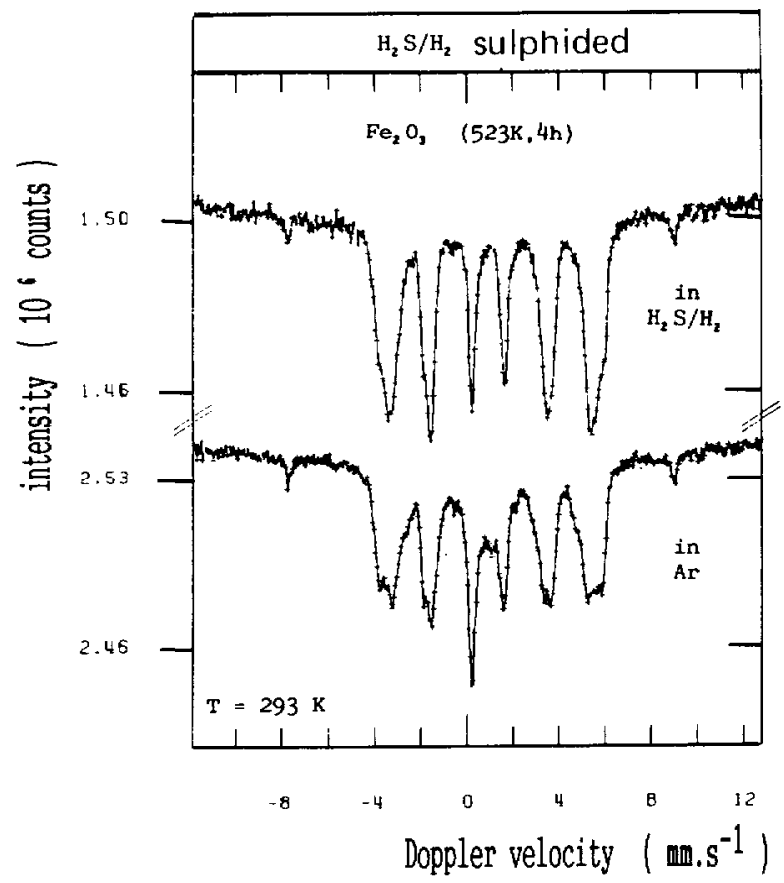

Fig. 3. Room temperature in-situ Mössbauer spectra of the sulphided $\mathrm{Fe}_{2} \mathrm{O}_{3}(523 \mathrm{~K}, 4 \mathrm{~h})$ sample and of the same sample after replacing the hydrogen sulphide-hydrogen environment by argon at 293 K. See Experimental for details of the sulphidation procedure and sample notation. 


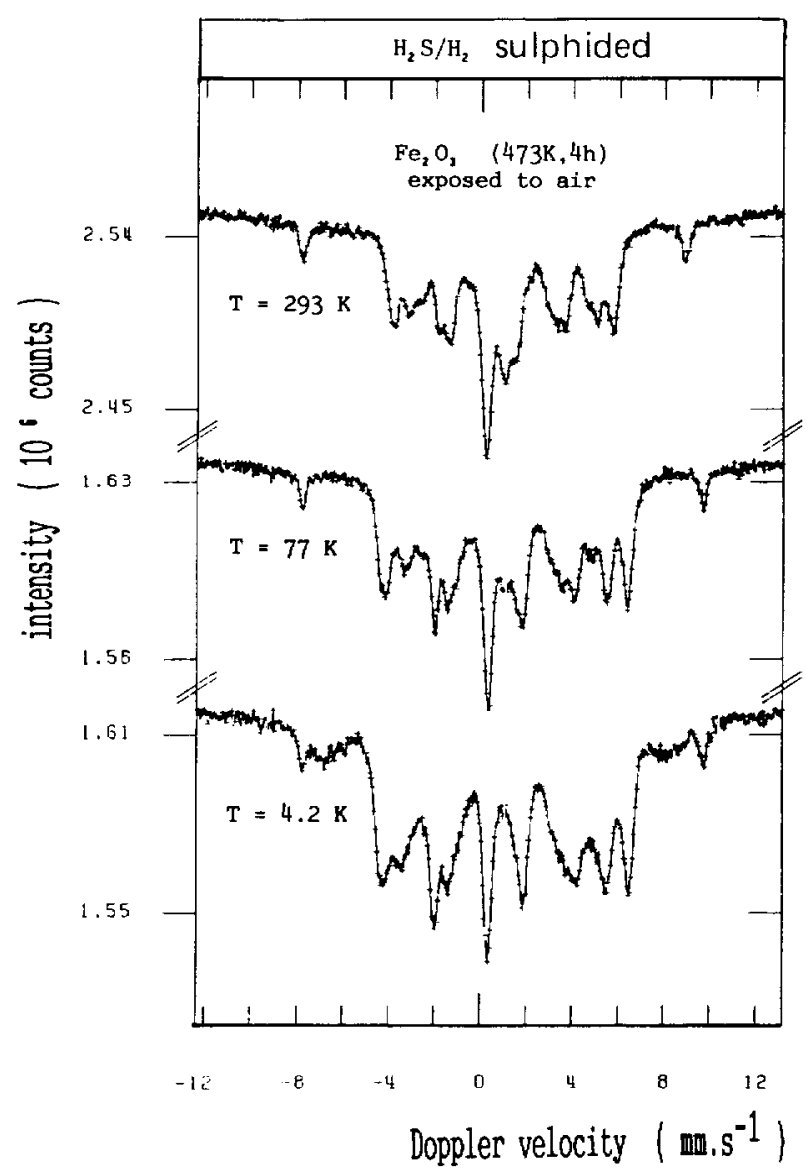

Fig. 4. Mössbauer spectra at 293,77 and $4.2 \mathrm{~K}$ of the sulphided $\mathrm{Fe}_{2} \mathrm{O}_{3}(473 \mathrm{~K}, 4 \mathrm{~h}$ ) sample exposed to air for one week at $293 \mathrm{~K}$.

magnetic hyperfine field $H_{\text {eff }}$ ) as well as the spectral contributions A deduced from the spectra are given in Tables 1 and 2.

Although the observed $\mathrm{Fe}_{1-x} \mathrm{~S}$ magnetic hyperfine fields tended to become less different, the largest field component found in $\mathrm{Fe}_{2} \mathrm{O}_{3}(673 \mathrm{~K}, 4 \mathrm{~h})$ was still smaller than the magnetic hyperfine field $(310 \mathrm{kOe})$ measured for the stoichiometric compound $\mathrm{FeS}$ from the meteorite Cape-York. The room temperature spectra of the latter and the $\mathrm{Fe}_{2} \mathrm{O}_{3}(673 \mathrm{~K}, 4 \mathrm{~h})$ sample are shown in Fig. 2.

It was necessary to keep the sulphided samples in the hydrogen sulphidehydrogen gas mixture during the Mössbauer experiment. This is clearly demonstrated in Fig. 3 and 4. In Fig. 3 we show the in-situ room temperature spectra of the $\mathrm{Fe}_{2} \mathrm{O}_{3}(523 \mathrm{~K}, 4 \mathrm{~h})$ sample and that of the same sample after removing the hydrogen sulphide-hydrogen environment by flowing argon at $293 \mathrm{~K}$. The small spectral contribution of the $\alpha-\mathrm{Fe}_{2} \mathrm{O}_{3}$ particles remained the same. How- 
ever, the sulphidic contributions were different, indicating a change in the composition of the sulphided sample by changing the surrounding gas phase form hydrogen sulphide-hydrogen to argon. Fig. 4 shows spectra of the $\mathrm{Fe}_{2} \mathrm{O}_{3}(473 \mathrm{~K}, 4 \mathrm{~h})$ sample exposed to static air at room temperature for one week, measured at 293,77 and $4.2 \mathrm{~K}$, respectively. By comparing the room temperature spectrum of the air-exposed sample $\mathrm{Fe}_{2} \mathrm{O}_{3}(473 \mathrm{~K}, 4 \mathrm{~h})$ with the original spectrum given in Fig. 1b, it follows that the exposure to air caused the appearance of a quadrupole doublet in the centre of the spectrum. This doublet can be ascribed to an iron(III) oxide compound formed through the reoxidation of the sample. At $4.2 \mathrm{~K}$ the doublet contribution to the spectrum disappeared while a sextuplet consisting of very broad absorption lines, indicating a broad distribution of magnetic hyperfine fields, appeared. This effect can be explained by superparamagnetic behaviour of either small iron oxide particles [1] or an oxidic surface shell on larger particles [23].

\section{Temperature-programmed sulphiding}

The TPS pattern of the well-characterized unsupported, model compound $\alpha-\mathrm{Fe}_{2} \mathrm{O}_{3}$ is shown in Fig. 5 . For clarity only the hydrogen sulphide partial pressure is given. Before the start of the temperature program hydrogen sulphide uptake was observed at room temperature. The amount of hydrogen sulphide involved corresponded to the amount required to flush argon from the reactor and replace it with the hydrogen sulphide-hydrogen-argon mixture. Therefore this hydrogen sulphide uptake did not indicate sulphiding of the sample at room temperature. Sulphiding started somewhat above room temperature when hydrogen sulphide uptake was observed together with production of water (not shown). It follows from Fig. 5 that sulphiding was complete at about $900 \mathrm{~K}$.

Between $450 \mathrm{~K}$ and $750 \mathrm{~K}$, hydrogen consumption was found, with peaks coinciding the "dents" in the hydrogen sulphide consumption peak at $460 \mathrm{~K}$, $600 \mathrm{~K}$ and $720 \mathrm{~K}$. This indicated that hydrogen sulphide was produced by re-

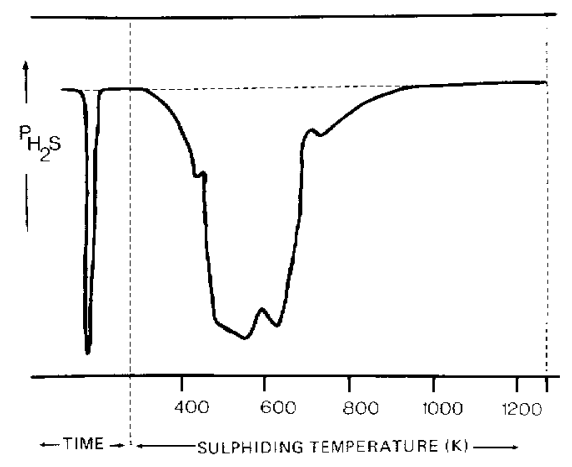

Fig. 5. TPS-pattern of unsupported $\alpha-\mathrm{Fe}_{2} \mathrm{O}_{3}$ particles. 
duction of sulphur or of sulphur-containing species [3,5]. The total hydrogen sulphide consumption corresponded to iron-to-sulphur ratio of 1 , and the hydrogen consumption with an iron-to-hydrogen ratio of about 3 . These ratios were close to the values found for $\mathrm{Fe}_{2} \mathrm{O}_{3}$ with a larger particle size [24].

\section{DISCUSSION}

From the experimental results shown in Fig. 3 it followed that even at room temperature the iron-to-sulphur ratio of the compounds formed had changed due to the replacement of the hydrogen sulphide-hydrogen environment by argon. Furthermore, it was found (see Fig. 1) that sulphided samples became partly reoxidized after exposure to air at room temperature for a period of one week. Therefore, it was absolutely necessary to keep the sulphided samples in the sulphiding gas mixture during characterization.

Lambert et al. [25] reported that in the iron-sulphur system the composition of the iron sulphides formed depended on the hydrogen sulphide-hydrogen ratio as well as the temperature. Using the results of these authors our results indicated that the hydrogen sulphide:hydrogen ratio at the surface of the particles would increase as a consequence of replacing the hydrogen sulphide-hydrogen gaseous environment by argon gas.

The temperature dependence of the oxidic contributions to the spectra of the sulphided samples after exposure to air (Fig. 4) can be explained by superparamagnetic behaviour of either small iron oxide particles [1] or an oxidic surface shell on large iron sulphide particles [23]. As superparamagnetic behaviour at room temperature was not observed for the sulphided samples, it was most likely that during the sulphidation procedure the size of the particles remained rather large. So, only the outer shell of the sulphided particles became reoxidized by the air exposure. However, in the case of carbon-supported $\mathrm{Fe}_{2} \mathrm{O}_{33}$ particles with a much smaller mean particle size $(<4 \mathrm{~nm})$ we observed superparamagnetic behaviour for the iron sulphide phase formed during treatment in hydrogen sulphide-hydrogen $(\mathrm{Fe}(673 \mathrm{~K}, 4 \mathrm{~h}) / \mathrm{C})$ and this iron sulphide phase could indeed be fully reoxidized by means of exposure to static air at $293 \mathrm{~K}$ for one week [26].

From our in-situ Mössbauer as well as TPS analysis it was concluded that the bulk of unsupported $\alpha-\mathrm{Fe}_{2} \mathrm{O}_{3}$ particles (diameter ca. $50 \mathrm{~nm}$ ) was not sulphided at room temperature. However, since the fraction of surface atoms of such particles was only about $5 \%$ and, furthermore, the effective Debye temperature of surface atoms is only about half that for bulk atoms [27], sulphidation of the surface iron atoms could not be excluded. In the case of a catalyst consisting of carbon-supported $\mathrm{Fe}_{2} \mathrm{O}_{3}$ particles with a much smaller mean particle size, we observed sulphidation of the particles to a large extent even at room temperature [26].Okutani et al. [28] found that an exothermic reaction occurred upon addition of a hydrogen sulphide-hydrogen gas mixture to un- 
supported $\alpha-\mathrm{Fe}_{2} \mathrm{O}_{3}$ at room temperature in a gas-circulating, high-pressure (4$10 \mathrm{MPa}$ ) DTA apparatus. Analyzing the crystal structures by ex-situ X-ray diffraction when this particular exothermic reaction was complete, these authors found diffraction lines corresponding to $\mathrm{FeS}_{2}$ and $\mathrm{Fe}_{3} \mathrm{~S}_{4}$ which had about half the intensity of diffraction lines of the major compound $\alpha-\mathrm{Fe}_{2} \mathrm{O}_{3}$. As we observed the formation of bulk iron sulphides only at higher temperatures, as shown by the Mössbauer spectra in Figs. 1a and b and the TPS-results given in Fig. 5, the apparent discrepancy between our results and those of Okutani et al. [28] may be due to the vigorous exothermic reaction at high pressure and the resulting local temperature increase observed by these authors.

All our in-situ Mössbauer experiments clearly showed a direct transformation of bulk $\alpha-\mathrm{Fe}_{2} \mathrm{O}_{3}$ into iron sulphides during the sulphidation process (see Figs. 1a and b). The formation of $\mathrm{Fe}_{3} \mathrm{O}_{4}$ between 500 and $600 \mathrm{~K}$ which was reported by Okutani [28] was not observed in our experiments at atmospheric pressure, so the reaction scheme seems to be less complex than that suggested by these authors.

McGormick et al. [29] proposed a model for the sulphidation of FeO (Wuistite) wafers. They studied the sulphidation of $\mathrm{FeO}$ with thermogravimetric techniques and found that during an initial transient stage a layer of FeS was formed on the wafer. It was assumed that this FeS layer was impermeable to oxygen. Therefore, oxygen would be conserved in the sample and there would be virtually no net oxygen transfer to, or from, the gas phase whatever its oxygen potential was. The growth of the FeS layer would proceed by the diffusion of iron from the $\mathrm{FeO}$ core to the $\mathrm{FeS}$-gas interface where it reacted with sulphur from the gas phase to form $\mathrm{FeS}$. They stated that the reaction rate was limited by the diffusion of iron through the intermediate $\mathrm{Fe}_{3} \mathrm{O}_{4}$ layer between $\mathrm{FeS}$ and $\mathrm{FeO}$ which grew concurrently with the $\mathrm{FeS}$ layer and at the expense of the $\mathrm{FeO}$ core. When the $\mathrm{FeO}$ core was completely converted to $\mathrm{Fe}_{3} \mathrm{O}_{4}$ the process stopped. Our observations clearly showed that such a model of sulphidation of iron oxides was wrong and only followed from the assumptions made by McCormick et al. [29] that the diffusivity of oxygen and sulfur anions in $\mathrm{FeO}$ and $\mathrm{Fe}_{3} \mathrm{O}_{4}$ were orders of magnitude less than the diffusivity of iron.

It follows from the TPS results shown in Fig. 5 that sulphiding of $\alpha-\mathrm{Fe}_{2} \mathrm{O}_{3}$ started at a relatively low temperature. The simultaneous consumption of hydrogen sulphide and production of water showed that the reaction proceeded through $\mathrm{O}-\mathrm{S}$ exchange which means that $\alpha-\mathrm{Fe}_{2} \mathrm{O}_{3}$ was not first reduced to $\mathrm{Fe}_{3} \mathrm{O}_{4}$ or FeO. From the TPS results only, it can not be excluded that reduction proceeded via iron (oxy) -sulphides. The "dents" in the hydrogen sulphide consumption peak at $460 \mathrm{~K}$ and $600 \mathrm{~K}$ coupled with hydrogen consumption peaks may suggest such a reduction behaviour. By combining the Mössbauer and the TPS results it can be shown that these "dents" in the hydrogen sulphide consumption peak and corresponding hydrogen consumption were due to a lowering of the sulphur content of the initially formed iron sulphides. 
According to the spectra in Fig. $1 \mathrm{a}$ and $\mathrm{b}$, the $\mathrm{FeS}_{2}$ formed which was associated with the electric quadrupole doublet in the centre of the resonant absorption spectra, was transformed into non-stoichiometric $\mathrm{Fe}_{1-x} \mathrm{~S}$ compounds by prolonged ( $4 \mathrm{~h}$ ) sulphiding at $423 \mathrm{~K}$ and $473 \mathrm{~K}$. The observed magnetic hyperfine fields for the sulphide compounds in $\mathrm{Fe}_{2} \mathrm{O}_{3}(473 \mathrm{~K}, 4 \mathrm{~h})$ agreed with those found by Thiel [19] $(302 \pm 2,252 \pm 2,228 \pm 2 \mathrm{kOe})$ in a sample of synthetic $\mathrm{Fe}_{7} \mathrm{~S}_{8}$ with the $4 \mathrm{C}$-type structure. By increasing the sulphiding temperature to 523 , 573 or $673 \mathrm{~K}$, the differences between the observed hyperfine fields gradually became smaller (see Fig. $1 \mathrm{~b}$ and Tables 1 and 2). This behaviour indicated that we were approaching the composition range with $x<0.09$ in which the iron vacancies in the non-stoichiometric $\mathrm{Fe}_{1-x} \mathrm{~S}$ compounds were no longer ordered. So, from the measured Mösbauer spectra it follows that the mean sulphur content of the iron-sulphur compounds formed decreases as the sulphidation time and/or the maximum temperature increases. Quantitative analysis of the TPS results showed that, finally, the total hydrogen sulphide consumption corresponded to a iron-to-sulphur ratio of 1 which is in line with the Mössbauer effect results described above. So, it can be concluded that the observed "dents" in the hydrogen sulphide consumption peak were due to the transition of $\mathrm{FeS}_{2} \rightarrow \mathrm{Fe}_{1-x} \mathrm{~S}$ and the continuous lowering of $x$ with increasing sulphidation time and/or increasing the maximum temperature.

The analyses of the Mössbauer spectra of the sulphided samples were carried out using only three different magnetic hyperfine sextuplets for representation of the sulphur compounds formed. Igaki et al. [18] analyzed their spectra in much more detail and proposed an assignment of the various components of the Mössbauer spectra to iron atoms with different vacancy configurations within the first, second and third neighbouring shells, labelled C, A and B, respectively. When an iron atom had no iron vacancy within these three neighbouring shells, the site was denoted by $\mathrm{O}$. As mentioned before, the observed magnetic hyperfine fields in the sulphided sample $\mathrm{Fe}_{2} \mathrm{O}_{3}(473 \mathrm{~K}, 4 \mathrm{~h})$ corresponded to those found by Thiel [19] in $\mathrm{Fe}_{7} \mathrm{~S}_{8}$ which has the 4C-type structure. This means, in terms of the nomenclature of Igaki et al. [18], that we are dealing with the sites $\mathrm{A}_{2}(300 \mathrm{kOe}), \mathrm{B}_{4}(258 \mathrm{kOe})$ and $\mathrm{B}_{2} \mathrm{C}_{1}(228 \mathrm{kOe})$. The hyperfine field of the $\mathrm{O}$-site corresponds to the hyperfine field for the sample $\mathrm{Fe}_{1-x} \mathrm{~S}$ with $x=0$ in which all iron sites occupy the $\mathrm{O}$-sites. We observed a hyperfine field of $310 \mathrm{kOe}$ at room temperature for a $\mathrm{FeS}$ sample from the meteorite Cape-York which has the $2 \mathrm{C}$-type structure. However, for the $1 \mathrm{C}$ type structure Thiel and Van den Berg [20] found a hyperfine field of $290 \mathrm{kOe}$ at room temperature. Since Ono and Ito [30] reported a hyperfine field of 276 kOe for a $1 \mathrm{C}$-type $\mathrm{Fe}_{1-\mathrm{x}} \mathrm{S}$ which, because of its low $x$ value $(x=0.047)$, would have a large fraction of occupied $\mathrm{O}$-sites, it seemed reasonable to assign this hyperfine field of the $1 \mathrm{C}$-type structure $(290 \mathrm{kOe})$ to the $\mathrm{O}$-site. Assuming that iron vacancies at the $\mathrm{C}, \mathrm{A}$ and $\mathrm{B}$ positions contributed independently to the hyperfine field, their contribution could be calculated by comparing the values 
of the hyperfine fields at the sites $\mathrm{A}_{2}, \mathrm{~B}_{4}, \mathrm{~B}_{2} \mathrm{C}_{1}$ with those at the $\mathrm{O}$-sites. These contributions, denoted as $\Delta H_{\mathrm{A}}, \Delta H_{\mathrm{B}}$ and $\Delta H_{\mathrm{C}}$ per vacancy, became $\Delta H_{\mathrm{A}}=+5$ $\mathrm{kOe}, \Delta H_{\mathrm{B}}=-8 \mathrm{kOe}$ and $\Delta H_{\mathrm{C}}=-46 \mathrm{kOe}$, and they were in reasonable agreement with the different contributions reported by Igaki et al. [18]. These authors used the derived values of $\Delta H_{\mathrm{A}}, \Delta H_{\mathrm{B}}$ and $\Delta H_{\mathrm{C}}$ to calculate the hyperfine fields of the additional iron sites which they used for deconvolution of the measured Mössbauer spectra. We believed that such an analysis of their spectra is not justified by the experimental accuracy, so we analyzed the Mössbauer spectra of the sulphide compounds formed with only three different magnetic hyperfine sextuplets. However, it can be noted from the hyperfine fields given in Tables 1 and 2 that the number of iron vacancies in the $\mathrm{Fe}_{1-x} \mathrm{~S}$ compounds formed decreased as the sulphidation time and/or the maximum temperature increased. The initially observed iron sites $A_{2}, B_{4}$ and $B_{2} C_{1}$ were changed into the iron sites $A_{1}, B_{2}$ and $B_{4}$. The spectral contributions of the different sites also indicated that the composition of the $\mathrm{Fe}_{1-x} \mathrm{~S}$ compound formed shifted towards lower values of $x$.

\section{CONCLUSIONS}

It was clearly demonstrated that it was absolutely necessary to keep the samples in the sulphiding gas mixture during characterization. For the model catalyst of unsupported $\alpha-\mathrm{Fe}_{2} \mathrm{O}_{3}$ particles (diameter ca. $50 \mathrm{~nm}$ ) no bulk sulphidation took place at room temperature and atmospheric pressure. As the sulphidation temperature increased a direct transformation of bulk $\alpha-\mathrm{Fe}_{2} \mathrm{O}_{3}$ into iron sulphides was observed without preceding reduction steps to $\mathrm{Fe}_{3} \mathrm{O}_{4}$ and $\mathrm{FeO}$. The iron-to-sulphur ratio of the iron sulphides formed during the sulphidation process was initially 2 and decreased to 1 with increasing sulphidation time and/or temperature. In-situ Mössbauer spectroscopy and the TPS technique are complementary techniques.

\section{ACKNOWLEDGEMENTS}

We thank Edo Gerkema for skilful assistance with the Mössbauer experiments and Prof. Dr. J.M. Knudsen (H.C. Øorsted Institute, University of Copenhagen) for the kind supply of the Cape-York meteorite sample of FeS. The temperature-programmed sulphiding experiments were performed at the Institute for Chemical Technology of the University of Amsterdam. Thanks are due to Dr. B. Scheffer for assistance with the TPS experiments and with interpretation of the results. 


\section{REFERENCES}

1 C.K. Groot, A.M. van der Kraan, V.H.J. de Beer and R. Prins, Bull. Soc. Chim. Belg., 93 (1984) 707.

2 C.K. Groot, V.H.J. de Beer, R. Prins, M. Stolarski and W.S. Niedźwiedź, Ind. Eng. Chem. Prod. Res. Dev., 25 (1986) 522.

3 B. Scheffer, J.C.M. de Jonge, P. Arnoldy and J.A. Moulijn, Bull. Soc. Chim. Belg., 93 (1984) 751.

4 P. Arnoldy, Thesis, University of Amsterdam, Amsterdam, 1985.

5 P. Arnoldy, J.A.M. van den Heijkant, G.D. de Bok and J.A. Moulijn, J. Catal, 92 (1985) 35.

6 P. Arnoldy, J.L. de Booys, B. Scheffer and J.A. Moulijn, J. Catal., 93 (1985) 112.

7 P. Arnoldy, J.A.M. van den Heijkant, V.H.J. de Beer and J.A. Moulijn, Appl. Catal., 23 (1986) 81.

8 B. Scheffer, E.M. van Oers, P. Arnoldy, V.H.J. de Beer and J.A. Moulijn, Appl. Catal., 25 (1986) 303.

9 S. Mørup, B.S. Clausen and H. Topsøe, J. Phys. Colloq. (Orsay, Fr.), 40 (1979) C2-88.

10 H. Topsøe, B.S. Clausen, R. Candia, C. Wivel and S. Mørup, J. Catal., 68 (1981) 433.

11 C. Wivel, R. Candia, B.S. Clausen, S. Mørup and H. Topsøe, J. Catal., 68 (1981) 453.

12 G. Hägg and I. Sucksdorf, Z. Phys. Chem., 22 (1933) 444.

13 F. Bertaut, Bull. Soc. Fr. Minér. Crist., 79 (1956) 276.

14 M.E. Fleet, Acta Cryst., B27 (1971) 1864.

15 A. Nakano, M. Tokonami and N. Morimoto, Acta Cryst., B35 (1979) 722.

16 E.F. Bertaut, Acta Cryst., 6 (1971) 557.

17 M. Tokonami, K. Nishiguchi and N. Morimoto, Am. Mineral., 57 (1972) 1066.

18 K. Igaki, M. Sato and T. Shinohara, Trans. Jpn. Inst. Met., 22 (1981) 627.

19 R.C. Thiel, Thesis, University of Groningen, Groningen, 1969.

20 R.C. Thiel and C.B. van den Berg, Phys. Stat. Sol., 29 (1968) 837.

21 A.M. van der Kraan and J.W. Niemantsverdriet, in G.J. Long and J.G. Stevens (Eds.), Industrial Applications of the Mössbaucr Effect, Plenum, New York, 1986, p. 609.

22 A.M. van der Kraan and J.W. Niemantsverdriet, in J.J. Bara, K. Reubenbauer and Z. Stachma (Eds.), Proc. of XX Winter School on Physics, Zakopane, Poland, vol.2, Institute of Nuclear Physics. Jagiellonian University, Krakńw, 1985, p. 356.

23 J.W. Niemantsverdriet, C.F.J. Flipse, A.M. van der Kraan and J.J. van Loef, Appl. Surf. Sci., $10(1982) 302$.

24 B. Scheffer, J.J. Heijinga, V.H.J. de Beer and J.A. Moulijn, to be published.

25 J.M. Lambert, Jr., G. Simkovich and P.L. Walker, Jr., Fuel, 59 (1980) 687.

26 W.L.T.M. Ramselaar, R.H. Hadders, V.H.J. de Beer and A.M. van der Kraan, to be published.

27 G.A. Somorjai, Chemistry in Two Dimensions: Surfaces, Cornell Lniv. Press, Ithaca, N.Y., 1981, p. 170.

28 T. Okutani, S.I. Yokoyama, Y. Maekawa, R. Furuichi and I. Ishii, Ind. Eng. Chem. Process Des. Dev., 22 (1983) 306.

29 S. McCormick, M.A. Dayananda and R.E. Grace, Met. Trans. B., 6B ( 1975$) 55$.

30 K. Ono and A. Ito, J. Phys. Soc. Jpn., 17 (1962) 1615. 